\title{
SISTEM PENGAMBILAN KEPUTUSAN DALAM PENERIMAAN PROYEK PEMBUATAN KAPAL MENGGUNAKAN METODE FUZZY
}

\author{
Algifanri Maulana \\ Fakultas Teknik, Program Studi Teknik Informatika \\ Universitas Putera Batam \\ Email: algifm@gmail.com \\ Sestri Novia Rizki \\ Fakultas Teknik, Program Studi Teknik Informatika \\ Universitas Putera Batam \\ Email: sestrinr@yahoo.com
}

\begin{abstract}
ABSTRAK
Dalam pelaksanaan suatu proyek pembangunan kapal, perencanaan biaya merupakan fungsi yang paling pokok dalam mewujudkan tujuan proyek seperti halnya kesesuaian biaya, waktu dan mutu perlu dilakukan secara terpadu dan menyeluruh, terlebih khusus dalam hal biaya diperlukan untuk upah dan bahan. Banyak kontraktor yang mengalami kerugian dalam proyek bangunan kapal karena harga penawaran proyek tidak mampu menutupi biaya - biaya operasional dan upah karyawan buruh. Salah satu penyebab kontraktor mengalami kerugian adalah tidak mampu menghitung biaya - biaya yang harus di keluarkan dalam proses pembangunan proyek kapal. Maka dari itu dibutuhkan sebuah system dalam Penyelesaian masalah sistem pengambilan keputusan dalam penerimaan proyek pembuatan kapal menggunakan metode Sugeno. Metode Sugeno ini mampu mengambil Sistem pengambilan Keputusan dalam penerimaan proyek kapal. Penelitian ini adalah logika fuzzy metode sugeno bisa diterapkan dalam pengambilan keputusan proyek pembangunan kapal di PT Karya Putra Karimun dengan memasukkan biaya upah karyawan, biaya material, biaya operasional dan harga proyek. Penyelesaian masalah produksi menggunakan konstanta atau fungsi matematika dari variabel input, dan pada proses defuzzifikasinya mengunakan metode rata-rata terpusat.
\end{abstract}

Kata kunci: logika fuzzy; metode sugeno fuzzyfikasi; fungsi implikasi.

\begin{abstract}
In the implementation of a ship building project, cost planning is the most basic function in realizing project objectives as well as the suitability of costs, time and quality needs to be done in an integrated and comprehensive manner, especially in the case of costs required for wages and materials. Many contractors suffer losses in ship building projects because the project offer price is unable to cover operational costs and wages of workers. One of the causes of contractors experiencing losses is not being able to calculate the costs that must be incurred in the process of building a ship project. therefore a system is needed in solving the decision-making system problems in receiving shipbuilding projects using the Sugeno method. This Sugeno method is able to take the Decision-making System in receiving ship projects. this research is fuzzy logic sugeno method can be applied in decision making of shipbuilding projects at PT Karya Putra Karimun by including employee wage costs, material costs, operational costs and project prices. Settlement of production problems using constants or mathematical functions of input variables, and in the process the defuzzification uses a centralized average method
\end{abstract}

Keywords: fuzzy logic; methods of sugeno fuzzyfication; the function of the implications.

\section{PENDAHULUAN}

Pada sekitar tahun 1960-1970, Sistem Penunjang Keputusan mulai diperkenalkan. Sistem Penunjang Keputusan dirancang untuk mengembangkan efektivitas dan produktivitas dari para manajer dan kaum profesional. Keputusan adalah tindakan yang dilakukan oleh setiap orang pada umumnya dari waktu ke waktu, baik hal itu dilakukan secara sadar maupun tidak sadar. Bahkan untuk mengambil keputusan yang dilakukan secara sadar memerlukan perhitungan yang cermat serta diperlukan berbagai pertimbangan, persiapan yang matang serta siap untuk membuat analisis. Pada tahun (1970), Scoot Morton menyampaikan konsep utama dari sistem pendukung keputusan yang mendefenisikan SPK suatu 
sistem interaktif yang berbasiskan komputer yang membantu Pengambilan Keputusan dengan menggunakan data dan model untuk memecahkan masalah yang tidak terstruktur [1].

Definisi SPK menurut Keen dan Scoot Morton (1978) adalah gabungan sumber daya individual yang intelektual dengan kemampuan komputer untuk meningkatkan kualitas keputusan yang diambil yaitu sebuah sistem yang dibantu oleh komputer untuk pembuatan keputusan yang berhubungan dengan masalah semi terstruktur [2]. Dalam pelaksanaan suatu proyek pembangunan kapal, perencanaan biaya merupakan fungsi yang paling pokok dalam mewujudkan tujuan proyek seperti halnya kesesuaian biaya, waktu dan mutu perlu dilakukan secara terpadu dan menyeluruh, terlebih khusus dalam hal biaya diperlukan untuk upah dan bahan. Banyak kontraktor yang mengalami kerugian dalam proyek bangunan kapal karena harga penawaran proyek tidak mampu menutupi biaya - biaya operasional dan upah karyawan buruh. Salah satu penyebab kontraktor mengalami kerugian adalah tidak mampu menghitung biaya - biaya yang harus di keluarkan dalam proses pembangunan proyek kapal. maka dari itu dibutuhkan sebuah sistem pendukung untuk pengambilan keputusan. Konsep logika fuzzy adalah salah satu cara yang dapat menyelesaikan masalah tersebut.

Logika fuzzy adalah metodologi sistem kontrol pemecahan masalah, yang cocok untuk diimplementasikan pada sistem, mulai dari sistem yang sederhana, sistem kecil, embedded system, jaringan PC, multi channel atau workstation berbasis akuisisi data, dan sistem kontrol. Metodologi ini dapat diterapkan pada perangkat keras, perangkat lunak, atau kombinasi keduanya. Dalam logika klasik dinyatakan bahwa segala sesuatu bersifat biner, yang artinya adalah hanya mempunyai dua kemungkinan, "Ya atau Tidak", "Benar atau Salah", "Baik atau Buruk", dan lain lain. Oleh karena itu, semua ini dapat mempunyai nilai keanggotaan 0 atau 1.Akan tetapi, dalam logika fuzzy memungkinkan nilai keanggotaan berada di antara 0 dan 1 . Artinya, bisa saja suatu keadaan mempunyai dua nilai "Ya dan Tidak", "Benar dan Salah", "Baik dan Buruk" secara bersamaan, namun besar nilainya tergantung pada bobot keanggotaan yang dimilikinya [4]. Alasan digunakannya Logika Fuzzy adalah:

1) Konsep Logika Fuzzy mudah dimengerti. Konsep matematis yang mendasari penalaran fuzzy sangat sederhana dan mudah dimengerti.

2) Logika Fuzzy sangat fleksibel.

3) Logika Fuzzy memiliki toleransi terhadap data-data yang tidak tepat.

4) Logika Fuzzy mampu memodelkan fungsi-fungsi nonlinear yang sangat kompleks.

5) Logika Fuzzy dapat membangun dan mengaplikasikan pengalaman- pengalaman para pakar secara langsung tanpa harus melalui proses pelatihan.

6) Logika Fuzzy dapat bekerjasama dengan teknik-teknik kendali secara konvensional.

7) Logika Fuzzy didasarkan pada bahasa alami.

Secara umum, Fuzzy Logic adalah sebuah metodologi "berhitung" dengan variabel kata-kata (linguistic variabel), sebagai pengganti berhitung dengan bilangan [1]. Kata-kata yang digunakan alam Fuzzy Logic memang tidak sepresiasi bilangan, namun kata-kata jauh lebih dekat dengan intuisi manusia. Manusia bisa langsung "merasakan" nilai dari variabel kata-kata yang sudah dipakainya sehari-hari. Demikianlah, Fuzzy Logic memberikan ruang dan bahkan mengeksploitasi toleransi terhadap ketidakpresisian. Fuzzy logic membutuhkan "ongkos" yang lebih murah dalam memecahkan berbagai masalah yang bersifat Fuzzy [3]. Dalam penelitian yang berjudul "Penentuan Jurusan di SMAN 8 Surakarta dengan Fuzzy Inference System (FIS) Mamdani" menghasilkan Fuzzy Inference System (FIS) Mamdani dapat digunakan untuk membangun sistem pendukung keputusan penentuan jurusan di SMAN 8 Surakarta dan berdasar pengujian yang dilakukan, nilai IPA dan IPS antara FIS 1 dengan FIS2 mempunyai nilai output yang tidak beda secara signifikan. Berdasar percobaan data seluruh siswa kelas X tahun ajaran 2008/2009, FIS 1 dan FIS 2 memberikan keputusan yang sama. FIS 1 lebih direkomendasikan untuk digunakan karena fungsinya lebih sederhana [4].

Jurnal Internasional dengan judul "Linguistic Fuzzy Rules in Data Mining: Follow-Up Mamdani Fuzzy Modeling Principle". Penelitian ini membahas tentang Fuzzy Rule-Based Systems (FRBSs) bahasa linguistic dengan menggunakan Fuzzy Inference System metode Mamdani. Hasil dari penelitian ini membuktikan kegunaan dari FRBSs bahasa linguistic dalam sebuah perkembangan dan masalah signifikan dalam data mining seperti klasifikasi dataset yang tidak seimbang dan khusus untuk mereka dengan tingkat ketidakseimbangan yang tinggi. Secara khusus, penelitian ini menunjukkan perilaku yang baik dari FRBSs hirarki linguistic, meningkatkan klasifikasi kinerja di daerah yang tumpang tindih antara minoritas dan mayoritas kelas dan mengungguli pohon keputusan $\mathrm{C} 4.5$ yang terkenal [5].

\section{METODOLOGI PENELITIAN}

Metodologi penelitian adalah gambaran langkah-langkah yang akan dilaksanakan dalam melakukan penelitian. Langkah-langkah penelitian ini selanjutnya akan digambarkan dalam bentuk kerangka kerja penelitian [7]. Metodologi ini perlu ditetapkan agar penelitian dapat dilakukan secara terstruktur. Langkah 
yang akan dilakukan harus mencakup mulai dari mempelajari masalah sampai dengan adanya suatu sistem yang dapat dihasilkan sehingga masalah dapat teratasi.

Analisa data yang di lakukan dalam menentukan kelayakan kapal menggunakan empat variable input dan satu variable output. Variable terdiri dari upah karyawan, biaya material, biaya operasional dan harga penawaran proyek. Output terdiri dariVariabel output keputusan diterima atau ditolak, atau decision [8]. contoh implementasi kedalam fuzzy logic dan perhitungan matematika hal ini dapat dilihat pada gambar 1 .

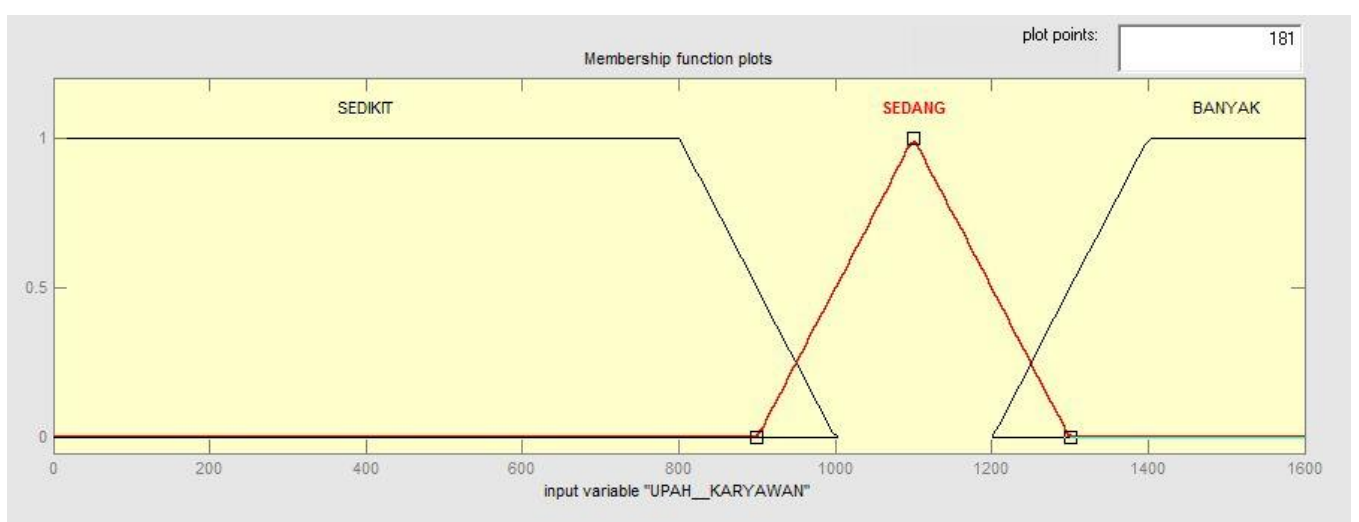

\section{Gambar 1. Representasi Fungsi Derajat Keanggotaan Variabel}

Analisa data yang di lakukan dalam menentukan kelayakan kapal menggunakan empat variable input dan satu variable output. Variable terdiri dari
1) Upah karyawan
2) Biaya Material
3) Biaya Operasional
4) Harga Penawaran Proyek

Output terdiri dari Variabel output keputusan diterima atau ditolak, atau decision. contoh implementasi kedalam fuzzy logic dan perhitungan matematika. Langkah Penyelesai Fuzzy Sugeno Langkah pertama menentukan variabel input dan variabel output yang merupakan himpunan tegas dan mengubah variabel input menjadi himpunan fuzzy dengan proses fuzzifikasi

Tabel 1. Himpunan fuzzy

\begin{tabular}{|c|c|c|c|c|}
\hline Fungsi & Variabel & $\begin{array}{c}\text { Himpunan } \\
\text { Fuzzy }\end{array}$ & $\begin{array}{c}\text { Semesta } \\
\text { Pembicaraan }\end{array}$ & Domain \\
\hline \multirow{12}{*}{ Input } & & Kecil & \multirow{3}{*}{$0-1600$} & {$\left[\begin{array}{llll}0 & 800 & 1000\end{array}\right]$} \\
\hline & Biaya Upah & Sedang & & {$\left[\begin{array}{lll}900 & 1100 & 1300\end{array}\right]$} \\
\hline & & Besar & & {$\left[\begin{array}{lll}1200 & 1400 & 1600\end{array}\right]$} \\
\hline & & Kecil & \multirow{3}{*}{$0-800$} & {$\left[\begin{array}{lll}0 & 400 & 500\end{array}\right]$} \\
\hline & Biaya Material & Sedang & & {$\left[\begin{array}{llll}450 & 550 & 650\end{array}\right]$} \\
\hline & & Besar & & [600 700800$]$ \\
\hline & & Kecil & \multirow{3}{*}{$0-120$} & {$\left[\begin{array}{lll}0 & 40 & 60\end{array}\right]$} \\
\hline & Biaya & Sedang & & {$\left[\begin{array}{lll}50 & 70 & 90\end{array}\right]$} \\
\hline & Operasional & Besar & & {$\left[\begin{array}{llll}80 & 100 & 120\end{array}\right]$} \\
\hline & Harga & Rendah & \multirow{3}{*}{$0-2500$} & {$\left[\begin{array}{llll}0 & 1500 & 1750\end{array}\right]$} \\
\hline & Penawaran & Sedang & & {$\left[\begin{array}{lll}1625 & 1875 & 2125\end{array}\right]$} \\
\hline & Proyek & Tinggi & & {$\left[\begin{array}{llll}2000 & 2250 & 2500\end{array}\right]$} \\
\hline \multirow{2}{*}{ Output } & Kenutusan & Diterima & \multirow{2}{*}{$0-1$} & [1] \\
\hline & Keputusan & Ditolak & & [0] \\
\hline
\end{tabular}


Langkah kedua yaitu mengubah variabel input menjadi himpunan fuzzy dengan proses fuzzifikasi

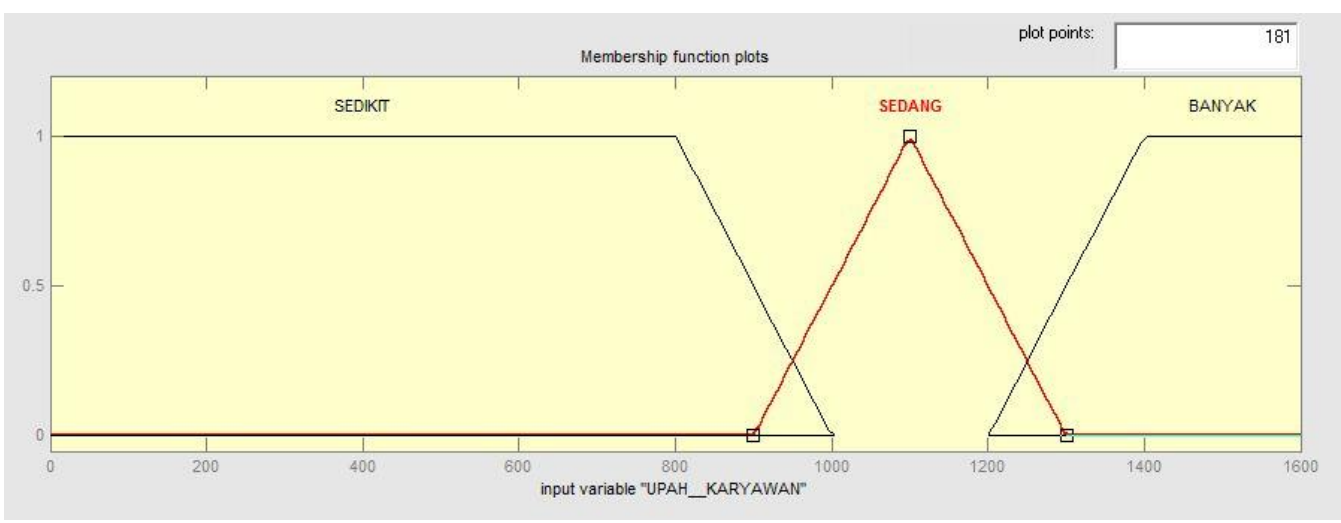

Gambar 2. Representasi Fungsi Derajat Keanggotaan Variabel Biaya Upah Karyawan

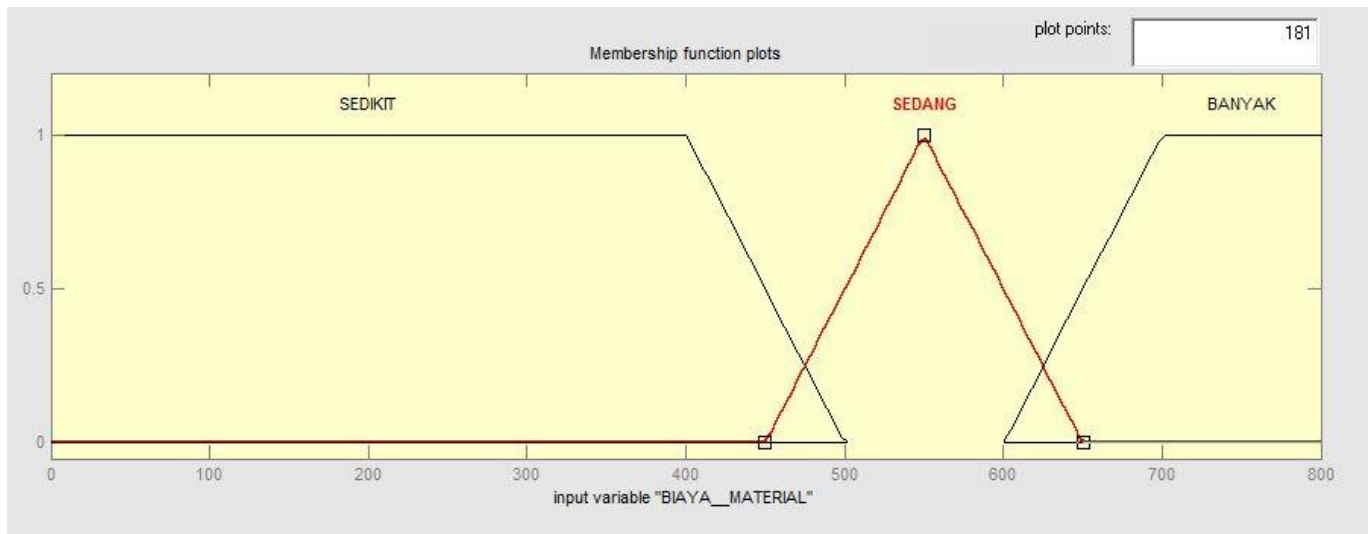

Gambar 3. Representasi Fungsi Derajat Keanggotaan Variabel Biaya Material

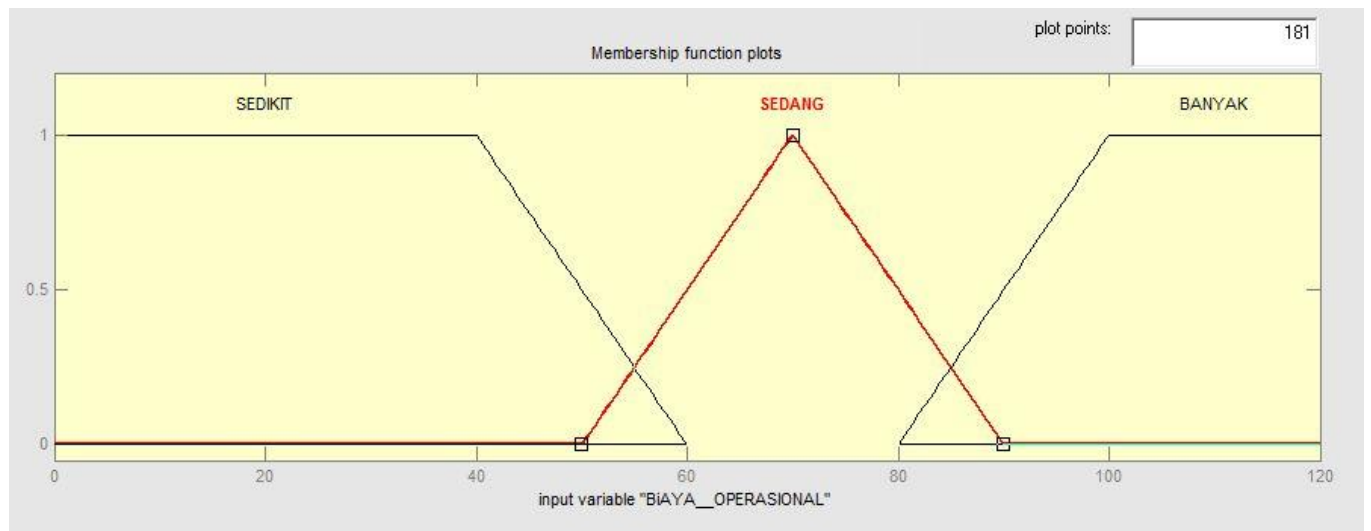

Gambar 4. Representasi Fungsi Derajat Keanggotaan Variabel Biaya Operasional 


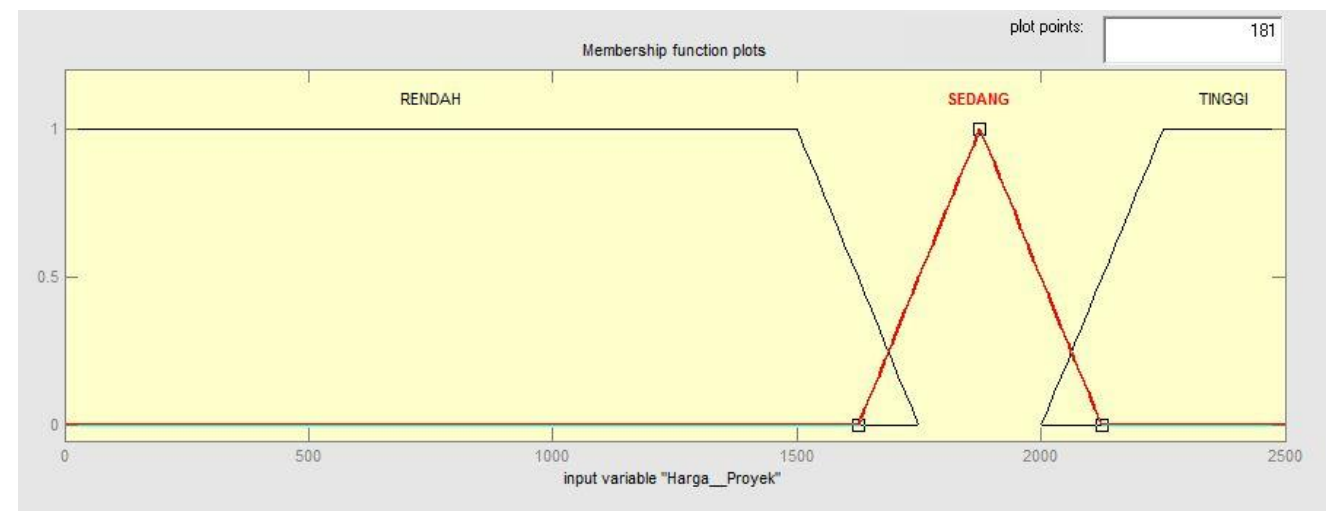

Gambar 5. Representasi Fungsi Derajat Keanggotaan Variabel Harga Proyek

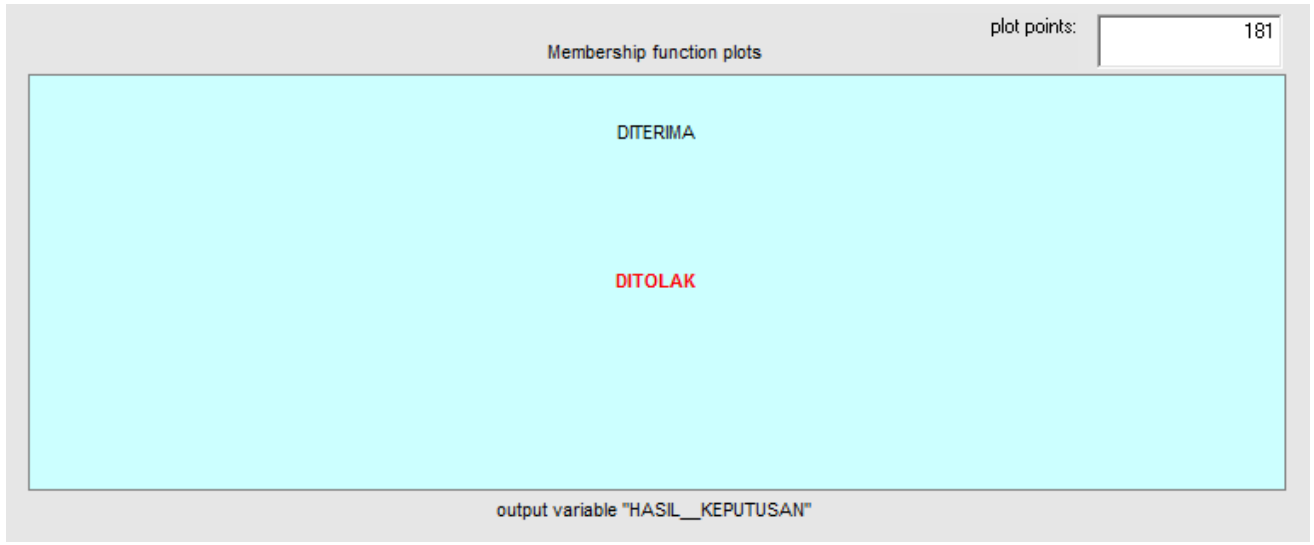

Gambar 6. Representasi Fungsi Derajat Keanggotaan Variabel Keputusan

\section{HASIL DAN PEMBAHASAN}

Biaya Upah Karyawan Fungsi derajat keanggotaan linier turun digunakan untuk merepresentasikan himpunan fuzzy rendah dan fungsi derajat keanggotaan linier naik untuk himpunan fuzzy tinggi. Fungsi derajat keanggotaan segitiga digunakan untuk merepresentasikan himpunan fuzzy normal. Bentuk representasinya adalah :

$$
\begin{aligned}
& \mu \text { Sedikit }[\mathrm{x}]=\left\{\begin{array}{ccc}
1 & ; & \mathrm{x} \leq 800 \\
\frac{1000-\mathrm{x}}{1000-800} & ; & 800 \leq \mathrm{x} \leq 1000 \\
0 & ; & \mathrm{x} \geq 1000
\end{array}\right. \\
& \mu \text { Sedang }[\mathrm{x}]=\left\{\begin{array}{ccc}
0 & ; \mathrm{x} \leq 900 \text { atau } \geq 1300 \\
\frac{\mathrm{x}-900}{1100-900} & ; & 900 \leq \mathrm{x} \leq 1100 \\
\frac{1300-\mathrm{x}}{1300-1100} & ; & 1100 \leq \mathrm{x} \leq 1300
\end{array}\right. \\
& \mu \text { Banyak }[\mathrm{x}]=\left\{\begin{array}{ccc}
0 & ; & \mathrm{x} \leq 1200 \\
\frac{\mathrm{x}-1200}{1400-1200} & ; & 1200 \leq \mathrm{x} \leq 1400 \\
1 & ; & 1400 \leq \mathrm{x} \leq 1600
\end{array}\right.
\end{aligned}
$$

Semua variabel masukan dan keluaran telah didefinisikan dan bentuk fungsi keanggotaan untuk tiap nilai linguistic dari tiap variabel juga telah didefinisikan dan dilabeli. Langkah selanjutnya adalah mendefinisikan IF-THEN rule dengan Rule Editor. 
a) [R10] If Biaya Upah Karyawan BANYAK, or Biaya Material BANYAK, or Biaya Operasional SEDIKIT, or Harga Proyek TINGGI, Then Hasil Keputusan DITERIMA

b) [R11] If Biaya Upah Karyawan BANYAK, or Biaya Material BANYAK, or Biaya Operasional BANYAK, or Harga Proyek TINGGI, Then Hasil Keputusan DITERIMA

c) [R12] If Biaya Upah Karyawan SEDIKIT, or Biaya Material BANYAK, or Biaya Operasional BANYAK, or Harga Proyek SEDANG, Then Hasil Keputusan DITOLAK

d) [R13] If Biaya Upah Karyawan SEDANG, or Biaya Material SEDANG, or Biaya Operasional BANYAK, or Harga Proyek SEDANG, Then Hasil Keputusan DITOLAK

e) [R14] If Biaya Upah Karyawan BANYAK, or Biaya Material SEDANG, or Biaya Operasional SEDANG, or Harga Proyek SEDANG, Then Hasil Keputusan DITOLAK

f) [R15] If Biaya Upah Karyawan BANYAK, or Biaya Material SEDANG, or Biaya Operasional BANYAK, or Harga Proyek SEDANG, Then Hasil Keputusan DITOLAK

Defuzzifikasi

$$
\begin{aligned}
& \left(\alpha^{1} * z^{1}\right)+\left(\alpha^{2} * z^{2}\right)+\left(\alpha^{3} * z^{3}\right)+\left(\alpha^{4} * z^{4}\right)+\left(\alpha^{5} * z^{5}\right)+\left(\alpha^{6} * z^{6}\right)+ \\
& \left(\alpha^{7} * z^{7}\right)+\left(\alpha^{8} * z^{8}\right)+\left(\alpha^{9} * z^{9}\right)+\left(\alpha^{10} * z^{10}\right)+\left(\alpha^{11} * z^{11}\right)+\left(\alpha^{12} * z^{12}\right)+ \\
& \left(\alpha^{13} * z^{13}\right)+\left(\alpha^{14} * z^{14}\right)+\left(\alpha^{15} * z^{15}\right)+\left(\alpha^{16} * z^{16}\right)+\left(\alpha^{17} * z^{17}\right)+ \\
& z=\frac{\left(\alpha^{18} * z^{18}\right)+\left(\alpha^{19} * z^{19}\right)}{\alpha^{1}+\alpha^{2}+\alpha^{3}+\alpha^{4}+\alpha^{5}+\alpha^{6}+\alpha^{7}+\alpha^{8}+\alpha^{9}+\alpha^{10}+\alpha^{11}+\alpha^{12}+\alpha^{13}+\alpha^{14}} \\
& +\alpha^{15}+\alpha^{16}+\alpha^{17}+\alpha^{18}+\alpha^{19} \\
& (0 * 1)+(0,1 * 1)+(0,4 * 1)+(0,4 * 1)+(0,2 * 1)+(0,4 * 1)+ \\
& (0,2 * 1)+(0,4 * 1)+(0,4 * 1)+(0,4 * 1)+(0,4 * 1)+(0,3 * 0)+ \\
& z=\frac{(0,2 * 0)+(0,4 * 0)+(0,3 * 0)+(0,3 * 0)+(0,4 * 0)+(0,3 * 0)+(0,3 * 0)}{0+0,1+0,4+0,4+0,2+0,4+0,2+0,4+0,4+0,4+0,4+0,3+} \\
& 0,2+0,4+0,3+0,3+0,4+0,3+0,3 \\
& 0+0,1+0,4+0,4+0,2+0,4+0,2+0,4+0,4+0,4+0,4+ \\
& z=\frac{0+0+0+0+0+0+0+0}{0+0,1+0,4+0,4+0,2+0,4+0,2+0,4+0,4+0,4+0,4+0,3+} \\
& 0,2+0,4+0,3+0,3+0,4+0,3+0,3
\end{aligned}
$$

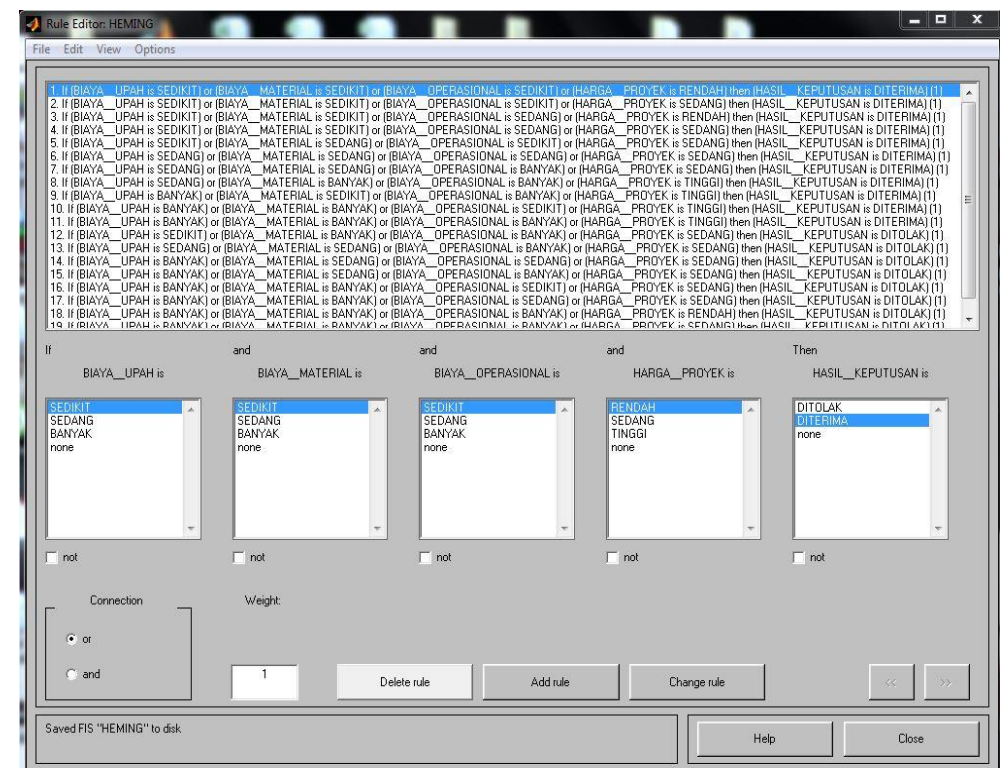

Gambar 7. Role Fuzzy 
Dan langkah terakhir atau keempat adalah mengubah output menjadi himpunan tegas dengan proses defuzzifikasi dengan metode centroid.

$$
\begin{aligned}
& \left(\alpha^{1} * z^{1}\right)+\left(\alpha^{2} * z^{2}\right)+\left(\alpha^{3} * z^{3}\right)+\left(\alpha^{4} * z^{4}\right)+\left(\alpha^{5} * z^{5}\right)+\left(\alpha^{6} * z^{6}\right)+ \\
& \left(\alpha^{7} * z^{7}\right)+\left(\alpha^{8} * z^{8}\right)+\left(\alpha^{9} * z^{9}\right)+\left(\alpha^{10} * z^{10}\right)+\left(\alpha^{11} * z^{11}\right)+\left(\alpha^{12} * z^{12}\right)+ \\
& \left(\alpha^{13} * z^{13}\right)+\left(\alpha^{14} * z^{14}\right)+\left(\alpha^{15} * z^{15}\right)+\left(\alpha^{16} * z^{16}\right)+\left(\alpha^{17} * z^{17}\right)+ \\
& z=\frac{\left(\alpha^{18} * z^{18}\right)+\left(\alpha^{19} * z^{19}\right)}{\alpha^{1}+\alpha^{2}+\alpha^{3}+\alpha^{4}+\alpha^{5}+\alpha^{6}+\alpha^{7}+\alpha^{8}+\alpha^{9}+\alpha^{10}+\alpha^{11}+\alpha^{12}+\alpha^{13}+\alpha^{14}} \\
& +\alpha^{15}+\alpha^{16}+\alpha^{17}+\alpha^{18}+\alpha^{19} \\
& 4 \quad(0 * 1)+(0,1 * 1)+(0,4 * 1)+(0,4 * 1)+(0,2 * 1)+(0,4 * 1)+ \\
& (0,2 * 1)+(0,4 * 1)+(0,4 * 1)+(0,4 * 1)+(0,4 * 1)+(0,3 * 0)+ \\
& \mathrm{z}=\frac{(0,2 * 0)+(0,4 * 0)+(0,3 * 0)+(0,3 * 0)+(0,4 * 0)+(0,3 * 0)+(0,3 * 0)}{0+0,1+0,4+0,4+0,2+0,4+0,2+0,4+0,4+0,4+0,4+0,3+} \\
& 0,2+0,4+0,3+0,3+0,4+0,3+0,3 \\
& 0+0,1+0,4+0,4+0,2+0,4+0,2+0,4+0,4+0,4+0,4+ \\
& z=\frac{0+0+0+0+0+0+0+0}{0+0,1+0,4+0,4+0,2+0,4+0,2+0,4+0,4+0,4+0,4+0,3+} \\
& 0,2+0,4+0,3+0,3+0,4+0,3+0,3
\end{aligned}
$$

$$
\begin{aligned}
& z=\frac{3,3}{5,8} \\
& z=0,57
\end{aligned}
$$

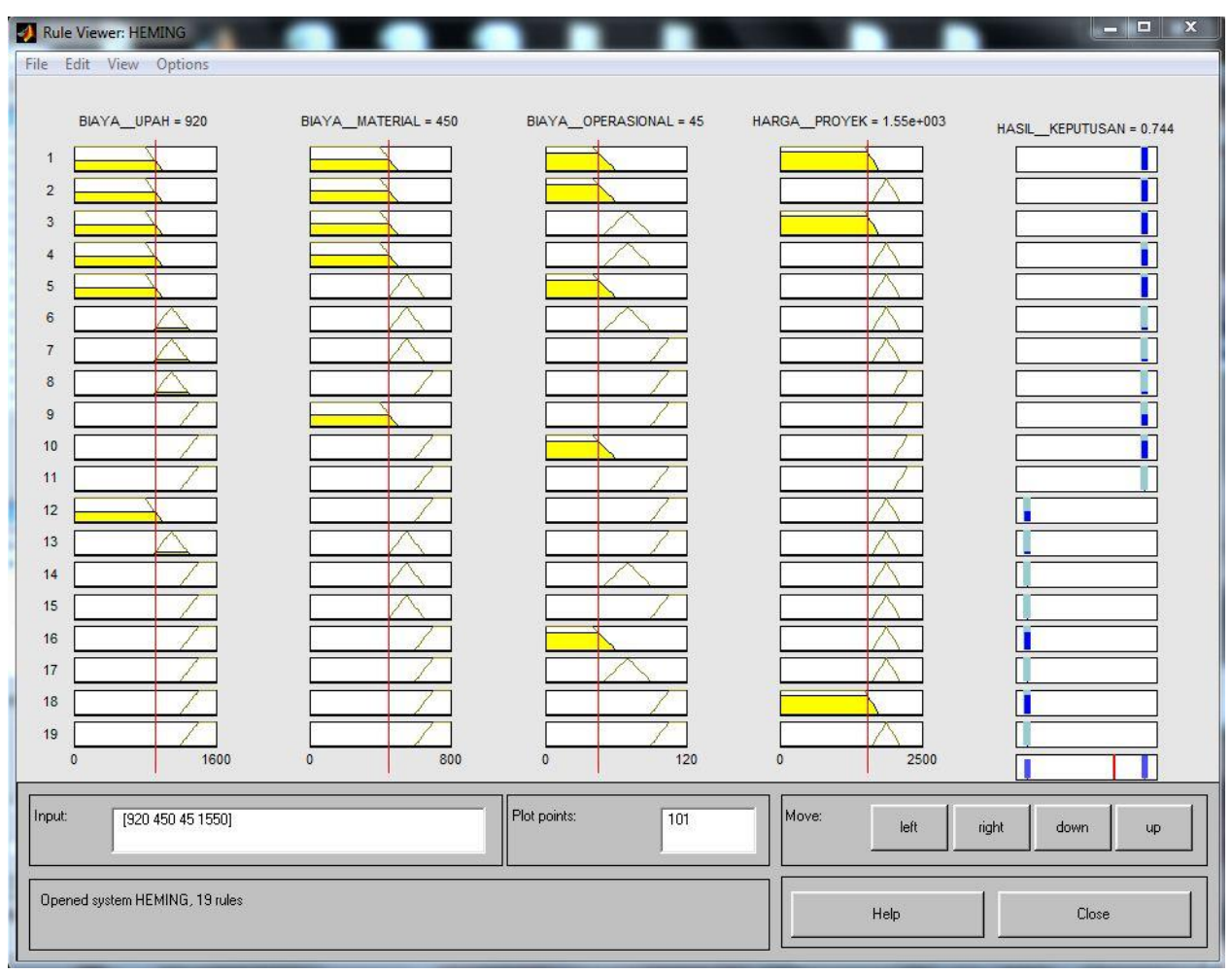

Gambar 8. Defuzzifikasi 


\section{KESIMPULAN}

Berdasarkan pembahasan penelitian dan analisa telah yang dilakukan, maka dapat disimpulkan beberapa hal sebagai berikut :

1) Berdasarkan Data dan proses penelitian yang dilakukan maka peneliti mendapatkan analisa menentukan hasil pengambilan keputusan dalam penerimaan proyek kapal membutuhkan variabel input dan variabel output. Variabel input yang didapatkan terdiri dari biaya upah karyawan, biaya material, biaya operasional dan harga proyek. Sedangkan variabel output berupa hasil keputusan .

2) Berdasarkan perhitungan Matlab dengan hasil pengujian pada gambar defuzifikasi diatas nilai input pertama untuk biaya upah kariawan 920, biaya material 450, Biaya operasional 45, dan Harga proyek 1.550.000.000 makan Hasil outpun berdasarkan Mtlab adalah 0.744 dengan keputusan diterima.

3) Penelitian ini adalah logika fuzzy metode sugeno bisa diterapkan dalam pengambilan keputusan proyek pembangunan kapal di PT Karya Putra Karimun dengan memasukkan biaya upah karyawan, biaya material, biaya operasional dan harga proyek. Sehingga menghasilkan output yang bisa dijadikan acuan dalam menentukan penerimaan proyek pembuatan kapal.

\section{DAFTAR PUSTAKA}

[1] Adhimantoro Singgih, "Mengetahui Tingkat Kematangan Buah Dengan Ultrasonik Menggunakan Logika Fuzzy," JNTETI, vol. 3, no. 1, p. 63, 2014.

[2] I. G. . Astawa, "Penerapan Logika Fuzzy Dan Jaringan Syaraf Tiruan Pada Sistem Penilaian Berbasis Komputer," J. Nas. Pendidik. Tek. Inform., vol. 1, no. 1, p. 67, 2012.

[3] H. H. C. R. dan Y. Inayati, "Sistem Pendukung Keputusan Pemilihan Jurusan Di SMU Dengan Logika Fuzzy," Tek. Inform. UPN Veteran, vol. 3, no. 1, 2008.

[4] K. S. dan H. Purnomo, Aplikasi Fuzzy Logic Untuk Pendukung Keputusan. Yogyakarta: Graha Ilmu, 2013.

[5] F. Fernandez, A., \& Herrera, "Linguistic Fuzzy Rules in Data Mining : Follow-Up Mamdani Fuzzy Modeling Principle," Comb. Exp. Theory, vol. 6, no. 2, pp. 103-122, 2012.

[6] R. dan T. L. Meimaharani, "Analisis Sistem Inference Fuzzy Sugeno Dalam Menentukan Harga Penjualan Tanah Untuk Pembangunan Minimarket," SIMETRIS, vol. 5, no. 1, p. 90, 2014.

[7] M. Nazir, Metode Penelitian, 8th ed. Bogor: Ghalia Indonesia, 2013.

[8] A. Naba, Belajar Cepat Fuzzy Logic Menggunakan MATLAB. Yogyakarta: Andi, 2009.

[9] P. dan P. P. Widodo, "Model Penduga Kinerja Pegawai Berdasarkan Pendekatan FIS Mandani: Studi Kasus Badan Kependudukan Dan Keluarga Berencana Nasional," Fakt. Exacta, vol. 7, no. 3, pp. 271-281, 2014.

[10] M. E. dan S. V. Sutojo, T., Kecerdasan Buatan, 1st ed. Yogyakarta: Andi, 2011. 